\title{
Redaksioneel
}

\section{Die nuwe landbounavorsingsraad - stigting en uitdagings}

Die te stigte landbounavorsingsraad moet beoordeel word teen die agtergrond van die bestaande landbounavorsingsorganisasie en -strukture aan die een kant en die behoeftes aan landbounavorsing vir die verdere ontwikkeling van landbou in Suider-Afrika aan die ander kant.

Deur 'n ewolusionêre proses - wat met die vestiging van die eerste landboukollege (naamlik Elsenburg) in 1897 en dit stigting van die Navorsingsinstituut vir Veeartsenykunde in 1908 , reeds voor Uniewording 'n aanvang geneem het - het daar 'n omvattende infrastruktuur vir landbounavorsing, tegnologie-ontwikkeling en tegnologieoordraging in Suid-Afrika tot stand gekom

Soos dit hoort, is daar 'n sterk landbounavorsingskomponent aan universiteite gesetel. Dit sluit universiteite met en sonder landboufakulteite in. Vir min of meer 50 jaar tot 1973 was landboudosente aan universiteite, betaalde amptenare van die Departement van Landbou en was daar 'n feitlik volledige integrasie in die beplanning, befondsing en uitvoering van landbounavorsing, tegnologie-ontwikkeling en tegnologieoordraging binne die owerheid en tersiêre onderwyssektore.

In 1973 is die landboufakulteite volledig by die universiteite ingelyf en het daar ' $n$ geleidelike verwydering tussen die landboudepartemente en die fakulteite ingetree. Dit is 'n onbevredigende toestand wat nie kan voortbestaan nie.

Sowel die navorsingsinstitute van die Departement as die verskillende navorsingsgroepe by universiteite kan roem op betekenisvolle bydraes tot die uitbouing van die landbouwetenskap en die ontwikkeling van 'n moderne landboubedryf in Suid-Afrika. Dit is duidelik dat die huidige situasie waarin die grootste landbounavorsingkomponent in die Eiesake-administrasie: Volksraad gesetel is en waarin daar nie sterk koördineringsmeganismes bestaan nie, hersien moet word.

Die Departement van Landbou-ontwikkeling het dus die inisiatief geneem om die proses vir die stigting van 'n outonome landbounavorsingsraad (LNR) wat sy volwaardige plek langs die ander bestaande wetenskapsrade kan inneem, aan die gang te sit. Die kabinet het reeds op 28 Junie 1989 die beginsel goedgekeur en opdrag gegee dat wetgewing voorberei moet word.

Die konsepwetsontwerp is reeds voltooi en is voorgelê aan bykans 80 instellings vir kommentaar. Reaksie van al die groepe is terug ontvang, wat daarop dui dat met weinig uitsonderings, oorweldigende steun vir die stigting van die LNR nou reeds bestaan. Die enkele uitsondering het laat blyk dat hulle eers meer inligting wou bekom voordat standpunt ingeneem kon word. Die konsepwetsontwerp word gedurende die 1990-sitting deur die Parlement oorweeg.

\section{OOGMERKE EN DOELSTELLINGS VAN DIE LNR}

Die oogmerke van die LNR is om:

(a) deur middel van navorsing die ontwikkeling en bestendiging van die landbousektor, insluitende die primêre produksiesektor en die nywerhede wat landbouprodukte verwerk, te bevorder;

(b) ander verbandhoudende werksaamhede te verrig wat deur die sentrale owerheid aan die LNR opgedra word.

Benewens genoemde aksies wat met 'n eie navorsingskapasiteit uitgevoer sal word, sal die LNR ook 'n koördinerende rol speel ten einde ander instellings soos tersiêre opvoedkundige inrigtings en andere op die sinvolste wyse moontlik te betrek by navorsing.

Die vraag kan met reg gevra word of die stigting van 'n LNR 'n goeie oplossing bied om die standaard van landboubediening in Suid-Afrika betekenisvol te verbeter.

Die volgende argumente kan aangevoer word om positief op die vraag te reageer:

1. 'n LNR wat alle bevolkingsgroepe sal bedien, maak dit moontlik om enige bekwame wetenskaplike aan te stel, ongeag die bevolkingsgroep waaraan hy of sy behoort. Die kundigheidspoel waaruit aanstellings gemaak moet word, word dus verbreed en dit sal ook die besware wat deur wetenskaplikes teen landbounavorsing as "eie saak" geopper word, uit die weg ruim.

2. Dit sal dit vir ander bevolkingsgroepe onnodig maak om daarop te begin aandring om hulle eie navorsingstrukture daar te stel. Hierdie stap sal dus aan die een kant uitgawes beperk en aan die ander kant beter benutting van skaars mannekrag verseker.

3. Indien so 'n versoek gerig word, sal die LNR ook navorsing vir onafhanklike buurstate en selfregerende nasionale state kan onderneem.

4. Die LNR sal benewens 'n jaarlikse parlementêre bewilliging ook addisionele fondse kan genereer deur kontraknavorsing.

5. Die LNR sal in 'n veel beter posisie as die Departement wees om aanknoping te vind by sekondêre nywerhede wat landbouprodukte verwerk.

\section{UITDAGINGS}

Die LNR sal sy volwaardige plek tussen die bestaande wetenskapsrade inneem en sal die gemeenskap van sy bestaansreg oortuig. Dit sal gedoen word op grond van die verklaarde voorneme om werk van uitnemende gehalte te lewer. Dit sal die vertroue wat die belanghebbende partye reeds het, verder uitbou.

Die strewe is om 'n volwaardige vennootskap te vestig tussen alle groepe wat sowel direk as indirek met landbou te make het. 